\title{
Introduction to Special Issue, Music in World Religions: A Response to Isabel Laack
}

\author{
Heather MacLachlan
}

Citation: MacLachlan, Heather. 2021 Introduction to Special Issue, Music in World Religions: A Response to Isabel Laack. Religions 12: 1044. https:// doi.org/10.3390/rel12121044

Received: 10 August 2021

Accepted: 19 November 2021

Published: 25 November 2021

Publisher's Note: MDPI stays neutral with regard to jurisdictional claims in published maps and institutional affiliations.

Copyright: (C) 2021 by the author. Licensee MDPI, Basel, Switzerland. This article is an open access article distributed under the terms and conditions of the Creative Commons Attribution (CC BY) license (https:// creativecommons.org/licenses/by/ $4.0 /)$.
Department of Music, University of Dayton, Dayton, OH 45469, USA; hmaclachlan1@udayton.edu

\begin{abstract}
This article serves to introduce a special issue of Religions, titled Music in World Religions. A 2015 article by religion scholar Isabel Laack claimed that the study of music and religion has been neglected by Laack's peers in the field of religions. Responding to Laack, I argue that scholars of music have been making important contributions to the study of music and religion and, indeed, have been addressing the twelve specific topics she highlights for decades. After summarizing academic works which respond to Laack's twelve categories of inquiry, I introduce each of the articles in this special issue, showing that each of these also address the gap in the literature that Laack perceived. Ultimately, I argue that transdisciplinarity in the study of music and religion is alive and well, and is exemplified both by historic writings and by those contained in Music in World Religions.
\end{abstract}

Keywords: music; religion; transdisciplinarity; review article; Islam; Afro-Caribbean religions; Hinduism; Sikh; Judaism; Buddhism

In 2015, Isabel Laack published a review article about the intersections of music and religion, titled "Sound, Music and Religion: A Preliminary Cartography of a Transdisciplinary Research Field". Laack is an award-winning scholar of religion, and her audience was her peers in religious studies. Laack made a strong call for transdisciplinarity in her article, arguing that scholars of religion should look to disciplines within the humanities, the social sciences, and the natural sciences to further their work on music and religion (Laack 2015, p. 222). Laack wrote that scholars of religion have mostly neglected the ubiquity of music within religious traditions and therefore, "a wide gap in the research remains. Too many expressions of religiosity have been overlooked, too many forms of religious experiences have been ignored, too many religious aspects in music have been left unseen ... " (Laack 2015, p. 221). She provided a "research outline" for future work on music and religion (Laack 2015, p. 237), identifying twelve categories of inquiry for other scholars to pursue, namely: sounds (of the music itself), texts, musical instruments, performance, efficacy, religious concepts of music, evaluation criteria, religious aesthetics and epistemologies, sociological aspects, media studies and semiotics, space, and history.

My own reading suggests that my fellow scholars of music have been attending to the very categories in the research outline proposed by Laack, and in some cases, their work on these issues dates back four or five decades. To demonstrate briefly, in this article I describe examples of scholarly publications that fit into each of Laack's twelve categories. My summary of just one example per category is not intended to provide a thorough review of music scholars' case studies of music and religion, but rather to make a straightforward argument: From the perspective of scholars who take music and musicians as their starting points, the study of music and religion is alive and well, and has been for many years. Pace Laack, I argue that there is no "wide gap in the research", but rather, a gap between scholars in different academic fields. This gap is the reason that an eminent scholar of religion would make the claim, in 2015, that the study of religion and music has been neglected. More importantly, the perceived existence of this gap is the reason that I and my fellow contributors to this special issue are grateful to be publishing our work in a journal titled Religions. Although we hold different titles ("ethnomusicologist" is mine), we identify as scholars who begin our investigations by focusing on music. We trust that 
our articles will speak to readers from a variety of fields, but most especially, to scholars of religion who are interested to learn more about how music intersects with religions and faiths around the world.

\section{Music Scholars Fulfilling Laack's Research Outline}

Sound: Laack is careful to point out that "music" is a concept that must be deployed carefully and defined precisely, given that it is used (or not used) differently in different human groups, including in different religious groups (Laack 2015, p. 233). With this caveat in mind, she acknowledges that music is a "sound phenomenon" and therefore calls for scholarly work on music and religion that centers on "the structural and theoretical analysis of the audible and of the different styles of music used in religious contexts" (Laack 2015, pp. 237-38). Regula Qureshi's (1993) article about qawwâlı̂ music-that is, Sufi Muslim devotional music-fulfills exactly these criteria. Qureshi, the pre-eminent scholar of this genre of music, explains how and why the sound of qawwâlî evolved during the twentieth century, as evidenced by examples of recorded performances. The article shows that qawwâlî song structure, vocal style, and use of melodic modes all changed over time, leading to an audible evolution in the style of this genre. To aid readers, Qureshi's article includes two examples of famous qawwâlî melodies, rendered in staff notation for visual comprehension.

Texts: Laack's outline includes the category of texts, that is, the words and lyrics contained in the songs, chants, and liturgies of religious musics around the world. She points out that this area of research is "familiar terrain" for scholars of religion, and scholars of music play close attention to texts as well (Laack 2015, p. 238). One interesting example is found in Anne K. Rasmussen's (2005) article "The Arab Musical Aesthetic in Indonesian Islam". Rasmussen explains that an Arabic secular song became "Islamic music" in the understanding of the Muslim Indonesian teenage girls who sang it, by virtue of the fact that the words of the song were in Arabic (Rasmussen 2005, pp. 78-79). To these young women, Arabic is the language of their religion, and therefore, a song with an Arabic text is a Muslim religious song. The performers sang the Arabic-language text in the musical style they believed appropriate for sacred music, transforming the sound of what was originally a popular love song. Rasmussen's article speaks to the significance of a song text and also describes the differences between secular and sacred sounds in the Indonesian Muslim soundscape. In this way, it fulfills both of Laack's first two categories-and as we will see below, many of the scholarly works cited here fulfill more than one of the categories in Laack's research outline.

Instruments: Laack calls for scholarly writing about the "religious symbolizations of [musical] instruments" saying that these "have not often been considered" (Laack 2015, p. 238). Scholars of music would beg to differ. One scholar who has devoted much of his career to understanding an instrument with enormous religious significance is Paul Berliner. Berliner has written at length about the mbira, a thumb piano used in Zimbabwe in a Shona religious ritual called a bira. In a 1975 article, for example, Berliner explained that the Shona people consider the mbira to be a "sacred instrument" and they liken its importance to that of the Bible for Christians (Berliner 1975, p. 132). The mbira is central to the success of a bira because the instrument's music summons the spirit of an ancestor who arrives to possess the body of a spirit medium and, through the medium, communicates with the humans present. Berliner went on to author a book entirely devoted to the mbira, the penultimate chapter of which provides a more detailed discussion of this instrument's role in a bira (Berliner 2020).

Performance: Music is embedded in all kinds of religious performances. Laack defines performance as "a multisensorial and socially and culturally highly complex phenomenon that assigns the body an important role in the generation of cultural meaning" (Laack 2015, p. 239). David Harnish, who is a contributor to this special issue, wrote a 2003 article which focuses on wayang Sasak, a shadow puppetry performance genre found in Java, Indonesia. Wayang Sasak dates back to the eighteenth century and was developed for the purposes of 
"introducing, teaching, and popularizing" Islam among the Javanese (Harnish 2003, p. 93). The music of the Javanese gamelan is integral to these shadow puppet plays. Classical-style presentations of the plays are understood to be potentially "transformative", at least by some aficionados, and their performance is therefore contested among modern orthodox Muslims in Java (Harnish 2003, p. 107). Harnish's richly-detailed description of one iteration of a wayang Sasak play shows that these performances are indeed "multisensorial and socially and culturally highly complex". Further, the puppeteer's careful differentiation of the right-hand side and left-hand side puppets has important religious significance (Harnish 2003, pp. 93, 102), and Harnish's explanation of this reminds us that the human body has an important role in generating meaning in the performance of wayang Sasak.

Efficacy: "The efficacy of sound and music refers both to its effects on humans and to religious theories about the effects of sound on supernatural beings or the cosmos" (Laack 2015, p. 239). Tiago de Oliveira Pinto's (1991) article explains how music affects both the supernatural beings called orixás, who are the focus of devotion in Afro-Brazilian religions like candomblé and umbanda, and the people who attend festas (the central ritual of these religions). The goal of a festa is "to establish communication with the sphere of" the orixás, so that ultimately adherents can be possessed by them (de Oliveira Pinto 1991, p. 73). Adherents must therefore dance using movements which imitate the orixás (de Oliveira Pinto 1991, p. 86); the dance movements are accompanied by specific rhythmic patterns played on drums and bells, and these patterns, too, are intended to imitate the characters of the orixás. Practitioners of Afro-Brazilian religions understand that by mimicking an orixá through their musical sounds and dance movements, they make it possible for the god to manifest himself or herself among devotees, and for their fellow adherents to enter a trance-like state. (Interestingly, the drummers who play the imitative rhythmic patterns are never themselves possessed by the orixás) (de Oliveira Pinto 1991, pp. 75-76). Pinto's article includes notation of four different drum patterns and is a clear delineation of the efficacy of musical sound in a religious context.

Religious Concepts of Music: In this category, Laack encourages scholars to investigate myths and religious theories which explain the origin and purpose of music in human life (Laack 2015, p. 239). Steven Feld's (1982) book Sound and Sentiment: Birds, Weeping, Poetics and Song in Kaluli Expression is a pre-eminent example of an extended study of religious concepts of music. Focusing on the Kaluli people of Papua New Guinea, Feld explains that an important myth (about a boy who dies and turns into a bird) undergirds their understanding not only of birds, but also of song, which the Kaluli view as the human translation of the birds' sounds. Feld's book also includes a detailed explanation of Kaluli music theory, which encompasses ideas about, and specific vocabulary for, concepts including the tonal center, a melody, and a musical composition, among others.

Evaluation Criteria: As Laack points out, musicians and other "discourse participants" in religious traditions engage in debates about many aspects of music making, including about how various musical sounds ought to be evaluated (Laack 2015, p. 239). Lois Ibsen Al-Faruqi is one music scholar who attended to these debates among Muslims. In her 1985 article, "Music, Musicians and Muslim Law", Al-Faruqi presented a hierarchy of genres of pitched-sound art prevalent in the Muslim world, organized from the most acceptable and legitimate at the top (the recitation of the Qur'an), through the controversial (such as music which includes instruments), and down to the consistently condemned (sensuous music associated with sinful activities). Al-Faruqi was careful to point out that there is no uniformity of agreement among the world's one billion Muslims, but her hierarchy, carefully laid out in a graph (Al-Faruqi 1985, p. 8), clearly reveals the evaluation criteria which are considered by both individual Muslims and Muslim communities when they evaluate the permissibility of various sounds and musics. 
Religious Aesthetics and Epistemologies: Laack is herself a specialist in religious aesthetics. Among the questions she poses to spark inquiry into this category is "Have particular cultures and religious traditions established sensory priorities?" (Laack 2015, p. 240). Michael Nijhawan answers that question with a ringing "Yes". Nijhawan identifies as a sociologist, but in his 2003 article he begins with musical sound to explore important dimensions of the Sikh faith. Nijhawan explains that "the central devotional practice of Sikhism is kirtan", during which Sikh congregants listen to and sing hymns from their sacred book, the Ädi Granth (Nijhawan 2003, p. 368). The Ädi Granth is organized not according to the lexical content of the hymns, but rather according to the ragas, or melodic modes, in which they must be sung. Other "prescriptions and codes of conduct", both musical and extra-musical, attach to the practice of kirtan, all of which contribute to the distinct performance style - that is, the preferred aesthetics—of the Sikh liturgy (Nijhawan 2003, p. 368). These musical practices are so intertwined with the Sikh understanding that the words of the holy book only "gain their full evocative power in the aesthetic experience of singers and listeners" (Nijhawan 2003, p. 368).

Sociological Aspects: Many questions can be asked about how religious music is socially organized. As Laack reminds readers, one of these is "How is a musical star born and kept shining?" (Laack 2015, p. 240). Virginia Danielson's (1997) biography of the bestselling musical artist in the Arab world, The Voice of Egypt: Umm Kulthum, Arabic Song, and Egyptian Society in the Twentieth Century, is an effective answer to this question. The book outlines how the career and celebrity persona of one musician was consciously shaped to appeal to the Muslim society in which she operated. Further, Danielson carefully attends to Umm Kulthum's involvement in Qur'anic recitation and Islamic song, explaining that her identity as a faithful Muslim was key to her success in Egypt and throughout the Middle East-thus making the book an example (like all the works cited here) of an investigation of the intersection of music and religion.

Media Studies and Semiotics: In her explanation of this category, Laack asks readers to consider, "What is musical 'meaning?'" and "How is 'meaning' generated?" (Laack 2015, p. 240). Scholars of music have addressed this question in a plethora of publications; however, there are few that link together a semiotic analysis with religious music, specifically. (Note: publications which explicitly link these two foci are more numerous after 2015, that is, after Laack published her call for more work to fulfill this category of inquiry. The pre-2015 works that do offer a rigorous approach to semiotics, religion, and music usually focus on music in Christianity - and I decided to exclude such works from my own review, about which I say more below). One exception to this trend is Stefano Jacoviello's (2011) article in the journal Semiotica. Jacoviello, a musicologist, describes in detail the career of the preeminent qawwâlî singer Nusrat Fatah Ali Khan. Recordings of qawwâli performances by Khan have been widely quoted, for example, in the soundtracks of Hollywood and Bollywood movies (Jacoviello 2011, pp. 324-25, 336). Furthermore, Khan participated in a number of fusion projects with Western popular music artists. In these ways his music travelled, gaining new meanings as it appeared in different contexts. Jacoviello argues forcefully against a postmodern analysis, which in its most extreme form cannot describe a piece of music, since postmodernism argues that musics exist only in the singular interpretations of individual listeners, and that language is similarly contingent and therefore inadequate as a tool for science (Jacoviello 2011, pp. 320-21). Rather, Jacoviello asserts that the meaning of a qawwâli song can be reliably ascertained from an understanding of the musical sounds themselves, as well as from the lyrics and from the context in which they appear; in other words, Jacoviello claims the importance and usefulness of semiotics for music analysis. His article is also of interest to scholars of religion because it complicates the notions of desecration and profanation as illustrated by this case study (Jacoviello 2011, pp. 326-27). 
Space: Laack has relatively little to say about how notions of space and place can relate to music and religion. She acknowledges, however, that spaces and places can be constructed through music (Laack 2015, p. 240). Sarah Daynes' 2004 book chapter, “The musical construction of the diaspora: the case of reggae and Rastafari" effectively links all of these categories of inquiry, focusing on the religiously-understood place at the heart of Rastafari faith: "Africa". Daynes acknowledges that reggae music and the Rastafari faith are not precisely coterminous. However, many reggae artists are adherents of Rastafari, and their religious beliefs are reflected in the lyrics of their songs (Daynes 2004, p. 26). Daynes' work shows the importance of reggae music in building a conception of Africa among immigrants from the West Indies in the United Kingdom. Africa is the spatial and temporal center of Rastafari theology, and members of the diaspora community view it as their true home. It is their participation in reggae music that fosters and sustains this religious idea among them.

History: In the final category of her research outline, Laack calls scholars to attend to continuity and change in religious musics, and continuity and change in religious traditions motivated by the performance of music. In my final example of a music scholar whose work fulfills Laack's outline, I point to Judah Cohen, a musicologist and historian of Jewish music in America. In a 2010 article, "Rewriting the Grand Narrative of Jewish Music: Abraham Z. Idelsohn in the United States", Cohen recounts the life of an important twentieth-century scholar of Jewish music. The article is an example of historiography, because Cohen contextualizes and interprets Idelsohn's work in light of the influences to which Idelsohn was subject as he was creating his "grand narrative". Having moved from Palestine to the American Midwest, where Reform Judaism was prominent, Idelsohn "reoriented his scholarship to address the needs of a progressive American Jewish minority" (Cohen 2010, p. 430). Idelsohn therefore emphasized, in both public lectures and in subsequent publications, that traditional Jewish tunes were the emanation of a unique "Jewish spirit", uncontaminated by foreign influences (Cohen 2010, p. 428). He further taught that Jewish chant was the "precursor to Christian chant", insisting on Jewish cultural achievements rather than positioning Jewish music as a derivation of Christian traditions (Cohen 2010, p. 429). Cohen's article goes on to explain that Idelsohn, a multitalented man, also composed a "foundational" and innovative songbook, which became widely used and thereby strongly influenced the sound of American Reform Jewish music in the United States (Cohen 2010, p. 435). Providing this richly detailed history, Cohen's article summarizes and also explains the changes in a significant repertoire of religious music.

Readers who choose to read any of the examples cited above will immediately note that each work could be usefully discussed from more than one perspective, meaning that each work could have served as an example for multiple categories in Laack's research outline. For example, Berliner's article about the mbira would be equally valuable in demonstrating the efficacy of music in religion; Nijhawan's article on Sikh kirtan could be presented as fulfilling Laack's category of "Texts;" etc. One of the joys of thoroughly researched studies of music is that they often draw from bodies of knowledge found in multiple fields of inquiry, which is to say, they are often transdisciplinary in their approach. Readers will also note that my review does not include any examples drawn from the study of music and Christianity. There are many such studies, and Religions has recently published two special issues devoted to music in Christian communities (see Music: Its Theologies and Spiritualities-A Global Perspective and Music and Spirituality). Therefore, I decided to devote my space in the pages of this issue to studies of music in other religions and faith traditions. My fellow contributors made the same choice, and we are delighted to present an entire issue dedicated to understanding music in religions beyond Christianity. In so doing we aim to expand the work of another recent special issue of Religions, titled Music, Sound and the Sacred. 


\section{Music in World Religions: An Introduction to This Special Issue}

This special issue contains ten articles. Each of them fulfills one or more of Laack's research categories. In addition, the articles work together to highlight other interesting themes connected to the study of music and religion. The articles by David Harnish and Megan Hynson, for example, both discuss music in religious communities in contemporary Indonesia. Together, these two articles discuss religious diversity in Indonesia and how the national priority of "Unity in Diversity" is negotiated by different religious groups. Further, both reveal that recently-instituted religious practices can - and do-become valued as "traditional" in a relatively short period of time.

David Harnish's article, “Tolerance of Ambiguity: Negotiating Religion and Sustaining the Lingsar Festival and Its Performing Arts in Lombok, Indonesia", reveals the kind of insight which is made possible by sustained scholarly attention. Harnish has been attending the Lingsar Festival and interviewing festival participants since 1983. As a result of his nearly forty years of participant observation, Harnish is able to document the profound changes in the music and dances presented during the festival over this time period. His article therefore responds to Laack's calls for work on both performance and history in the study of religion and music. As Harnish explains, the 350-year-old festival has long been promoted as a site of interreligious harmony, showcasing the friendly relationships between the (minority) Hindu Balinese people and the (majority) Muslim Sasak people in Lombok. However, both groups advance competing narratives about which group founded the ancient temple compound where the festival is held. Moreover, both groups have added particular performances to the festival schedule in recent decades, and discontinued others, in efforts to make their contributions more explicitly Hindu (on the part of the Balinese) and more explicitly Muslim (on the part of the Sasak). Harnish explains that these changes make sense in the context of the larger political shifts on the island and in the nation of Indonesia during the twentieth and twenty-first centuries. Sasak people, in particular, have good reasons to identify themselves as increasingly orthodox Muslims, in concert with similar trends on the neighboring island of Java, where the capital city is located. The changes at the festival, all of which have occurred before audiences of thousands, would seem to necessitate explanation-yet, as Harnish's interviews show, participants generally account for the innovations by saying they are "traditional" and (in at least one case) "have been going on for centuries". The willingness of festival participants to tolerate ambivalence and ambiguity is an important factor in their ability to describe the recent changes at the festival as traditional.

Megan Hynson's article, "'A Balinese Call to Prayer': Sounding Religious Nationalism and Local Identity in the Puja Tri Sandhya", describes in detail the sound of a relatively new Balinese Hindu mantra. As Hynson's reveals, the Puja Tri Sandhya is an invented tradition, broadcast publicly since the 1980 s as a way of reforming and legitimizing Balinese Hinduism by giving it a daily "call to prayer" that is analogous to both Muslim and Christian calls to prayer. It can thus be understood as part of an elite project intended to foster a sense of religious nationalism among Balinese people; as Hynson explains, the notion of religious nationalism is central to contemporary Indonesian citizenship. At the same time, the Puja Tri Sandhya has been embraced by local Hindus, who emphasize its connections to their long held (pre-reform) religious beliefs and practices. Hynson further explains that the traditional gamelan music that is always heard as an accompaniment to the mantra is deeply important in making these connections, because the instruments used are the same as those played in temples where ancient rituals continue to be celebrated. This article, which includes a detailed summary of twentieth-century political developments in Bali, fulfills Laack's categories of sound, instruments, musical meaning (semiotics), and history.

Hynson's article also addresses another priority for scholars represented in this special issue, namely, querying the boundary between the secular and the sacred. The articles by Duncan Reehl and David Font-Navarrete pay particular attention to instances of music traversing, and therefore calling into question, this boundary. 
Duncan Reehl explores the expanding sound world of Japanese Mahayana Buddhism in his article, "Musicalizing the Heart Sutra: Buddhism, Sound, and Media in Contemporary Japan". He reveals that during the past decade, Japanese monks and laypeople have created numerous musical settings of the Heart Sutra, one of the best-known sutras of Japanese Buddhism. Throughout Japanese musical modernity, the realms of Buddhist practice and popular music were distinct. However, in recent years monks have created musical settings of the Heart Sutra, which fuse its vocalization and traditional instrumental sounds with popular music performance styles and techniques, as a way of propagating Buddhist teaching and making Buddhism relevant to a younger generation that feels estranged from Buddhism and institutional religions. In so doing, these monks effectively blur the boundary separating the sacred from the secular. Contemporary Japanese people welcome the musicalization of the Heart Sutra, as is evident in their internet commentary, although their reception is varied and the practice of musicalizing sutras is still very marginal within Temple Buddhist institutions. Reehl's article is a worthy contribution to Laack's category of texts, because it illuminates the most recent evolution in the centuries-long life of a religious text, showing that the text not only sounds different as it is musicalized, but also that it gains new importance in the lives of Japanese people, many of whom do not even usually identify as Buddhists.

David Font-Navarrete's article, "Writing Orisha Music: Text, Tradition, and Creativity in Afro-Caribbean Liturgy", focuses on the origins of songs used in the worship of orishas (the gods in religious traditions of the African diaspora such as candomblé, santeria, vodou, and lukumi). These liturgical songs are broadly believed to have been inherited from enslaved Africans, who brought their languages and religious understandings to the Americas during the 17th, 18th, and 19th centuries. This belief is part and parcel of the larger narrative surrounding the history of Africans in the Caribbean, a narrative which is increasingly promoted by entities such as the Cuban government. However, as Font-Navarrete's interview with Juan Garcia (a prominent Cuban folklore artist and orisha priest) shows, one widely-sung orisha song was originally composed for a secular theatrical production in the 1970s. It subsequently became part of the sacred practice of orisha worshippers in Cuba and in the United States. This song is just one example of the corpus of songs which come into the orisha liturgy in at least five different ways. This article contributes to Laack's category of religious concepts of music, showing how one faithful practitioner adheres to the origin story about music in his religion while simultaneously contributing new material to that religion's liturgy.

Another article in this special issue that focuses intently on religious concepts of music is Inderjit Kaur's "Theorizing the (Un)Sounded in Sikhī: Anhad, Sabad, and Kīrtan". Kaur provides a rich introduction to Sikh religious teaching and, in particular, to the function of collective singing (kīrtan) within the tradition. She points out that, while other scholars have theorized the important Sikh concept of anhad as an abstraction, in fact, the scriptures frequently describe it using musical connotations (including specific musical instruments). Anhad, she argues, can and should be understood as the universe's eternal, limitless vibration. The reason that kirtan is so central to Sikh practice is that it consists, like all musical sounds, of vibrations which are produced in and which resonate in the physical bodies of worshippers. The primary function of kirtan, therefore, is not to teach doctrine or morality, but to convert "the infinite vibration to finite audible vibrations". In other words, kīrtaning brings Sikhs into a "state of attunement" with the formless vibration of anhad, and thereby enables them to experience a union with the divine. As this brief summary shows, Kaur's article can also be read as a contribution to Laack's category of efficacy, in that it provides a clear accounting for the effect of music on religious practitioners.

A third important theme that emerges in this special issue - and which, again, overlaps with Laack's research outline-is that historical developments impact religious understanding and practice. This idea is important in David Harnish's and Megan Hynson's articles (discussed above) and is a particular focus in the articles by Essica Marks and Sara Black Brown. These latter two scholars detail the historical events which led to the emergence 
of diaspora religious communities and reveal the profound influence of the diaspora experience on the development of religious musics among such groups.

Essica Marks describes the sounds of two Jewish liturgical traditions in her article "Music, History and Culture in Sephardi Jewish Prayer Chanting". Prayer chanting occurs during the fixed liturgical services common to Jews around the world; although the texts used during these services do not vary, the melodies and rhythms used by cantors to express those texts certainly do. Marks delineates in detail how cantors in two Sephardic Jewish traditions (the Jerusalem-Sephardi and the Spanish-Portuguese) musicalize various liturgical texts, and argues that the marked differences between them are explained by the fact that both are strongly influenced by the dominant musical cultures in which these traditions developed. Although both the Jerusalem-Sephardi and the Spanish-Portuguese communities have their origin in fifteenth-century Spain, their migrations to different diaspora destinations have resulted in different musical priorities-and thus, differentsounding prayer chanting-for each group. Musical transcriptions of examples from both traditions illuminate the contrasts between them and put Marks' article into Laack's categories of sound and history.

Whereas Marks emphasizes change in musical sound, Sara Black Brown focuses on the continuity of the kirtan tradition, which developed among Indian Hindus and is sustained by American Hindus today. In her article "From Meditation to Bliss: Achieving the Heights of Progressive Spiritual Energy Through Kirtan Singing in American Gaudiya Vaishnava Hinduism", Black Brown provides a thorough explanation of the religious rationale for congregational kirtan singing among American Hindus of the Vaishnava denomination. To chant the name of the god Krishna is to experience Krishna's presence, and as Brown reminds readers, the notion that the Divine is present when humans evoke his or her name is a notion common to many religions. The kirtan musicians who lead the musical invocations of Krishna's name deploy a consistent series of musical techniques, techniques which increase the intensity of the musical-spiritual experience over time and move the participants from stasis to ecstasy. These techniques are common to many musics which originate in India, and are used today in Hindu gatherings in the United States. Brown provides a thick description of one instance of kirtan singing in Florida, including transcriptions of the melodies sung during the event, to exemplify how these musical techniques move participants from meditative contemplation to joyful and playful dancing. Her article responds to Laack's call for work on the sound of religious music, giving readers a clear understanding of how one particular tradition sounds and explaining why it sounds that way. With its detailed account of the development of the Vaishnava community in the United States, this article also contributes to Laack's category of history.

A fourth intriguing theme is contained in this special issue: religious musics sometimes function to provide encounters with the Divine and to express the dissenting voices of lay individuals outside of the control of the dominant religious elite. Heba Arafah Abdelfattah and Uttaran Dutta et al. write about case studies that provide evidence for this phenomenon, albeit from different perspectives; Abdelfattah makes this claim on behalf of music listeners, whereas Dutta and his colleagues focus on two music performers.

Heba Arafah Abdelfattah's article, "The Ibtihalat in the Digital Age: Public and Private Domains" focuses on a genre of Islamic hymns, which are short Arabic-language devotional songs performed by solo singers who may or may not be accompanied by musical instruments. The ibtihalat genre originated in the twentieth century and has become very widely appreciated in the twenty-first, thanks to its dissemination via social media. It is now so influential in Egypt that Christians too sing some of the best-known songs in the genre, and its performance style was used by a contemporary composer who created music for the words of an ancient hymn to the Egyptian god Isis. Abdelfattah argues that ibtihalat are very popular because they engender a form of idrak, a kind of consciousness associated in Islamic teaching with the time before the Islamic message was revealed to the Prophet. During this time, humans were necessarily uncertain about the nature of the Divine and therefore had to ask questions, entertain skepticism, and engage in self-assessment. Listen- 
ing to an ibtihal today, individual Muslims are invited to reflect on themselves and their own spiritual lives, which begin, as do the spiritual journeys of all people, in the universal human consciousness (idrak). Public performances of these hymns therefore provide a private domain for believers to interact with the Divine outside of the control of religious authorities and beyond the realm of long and intricate Islamic legal debates. With her detailed description of the development of one particular hymn, and with her analysis of the meaning of its words, Abdelfattah contributes to Laack's categories of history and texts.

Uttaran Dutta, Soham Ghosh, Priyam Ghosal, Panchali Banerjee, Samya Srimany, and Sahana Mukherjee are co-authors of "Songs of Dissent and Consciousness: Pronouncements of the Bauls of Rural Bengal". The Bauls are the self-designated dissenters from the dominant religious traditions of Bengal (Hinduism and Islam). As such they play a prophetic role, critiquing the failures of normative religion and articulating their own vision for human liberation-and crucially, they do this through music. The authors argue that, too often, scholars of South Asia have dismissed the Bauls as members of a small and highly esoteric sect (and other commenters have criticized them as heretics and cult members). In their article, they focus on the songs of two prominent twentieth-century Baul singers, explaining that these songs speak to contemporary injustices and give voice to millions of poor and exploited people. The songs, therefore, constitute an important and non-violent form of resistance to the status quo in Bengal today, because they aim to foster in their audience an alternative vision for human society. The article forcefully advances the claim that people on the margins, using the seemingly "passive" strategy of musicking, have the potential to make a powerful difference and, therefore, deserve the serious attention of the academy. Furthermore, with its detailed analysis of several song texts, the article fulfills Laack's call for further scholarly work on texts.

The tenth article in this special issue points us to a new and valuable resource for scholars of music and religion. Dustin Wiebe explains in "Music and Religion: Trends in Recent English-Language Literature (2015-2021)", that he and his colleagues have established an online "semi-public" bibliography. Titled Religion, Music, and Sound Bibliography (RMSB), at the time of writing the bibliography lists nearly 650 English-language sources. These sources cover topics related to music and sound (which, as Wiebe notes, are carefully differentiated by many religious adherents) and to religion and spirituality. All of the sources were published between 2015 and 2021, and the hope is that the RMSB will continue to grow over the coming years as scholars continue to publish on these topics. Wiebe's overview of the RMSB reveals that English-language scholarship of the past six years is broad and rich, with contributions focusing on many different groups and geographic regions, as well as different religious traditions and different spiritually resonant musics. Wiebe highlights several themes which emerge from the RMSB, namely: gender and sexuality, race and ethnicity, indigenous traditions, and medical ethnomusicology and music therapy. Most importantly, he invites readers to contribute to the RMSB, and I second his invitation here. By adding their own publications to the RMSB, scholars-who are "discourse participants" regarding music and religion-will illuminate the debates engaged in by academics; they will thereby fulfill Laack's category of evaluation criteria. Further, they will address the larger problem perceived by Laack, showing that they constitute a transdisciplinary community which is dedicated to thoroughly investigating the intersections of music and religion.

Funding: This research received no external funding.

Conflicts of Interest: The author declares no conflict of interest.

\section{References}

Al-Faruqi, Lois Ibsen. 1985. Music, Musicians and Muslim Law. Asian Music 17: 3-36. [CrossRef]

Berliner, Paul. 1975. Music and Spirit Possession at a Shona Bira. African Music 5: 130-39. [CrossRef]

Berliner, Paul. 2020. The Art of the Mbira: Musical Inheritance and Legacy. Chicago: University of Chicago Press.

Cohen, Judah M. 2010. Rewriting the Grand Narrative of Jewish Music: Abraham Z. Idelsohn in the United States. The Jewish Quarterly Review 100: 417-53. [CrossRef] 
Danielson, Virginia. 1997. The Voice of Egypt: Umm Kulthum, Arabic Song, and Egyptian Society in the Twentieth Century. Chicago: University of Chicago Press.

Daynes, Sarah. 2004. The musical construction of the diaspora: The case of reggae and Rastafari. In Music, Space and Place. Edited by Sheila Whitely, Andy Bennett and Stan Hawkins. London: Routledge, pp. 25-41.

de Oliveira Pinto, Tiago. 1991. Making Ritual Drama: Dance, Music, and Representation in Brazilian "candomblé" and "Umbanda". The World of Music 33: 70-88.

Feld, Steven. 1982. Sound and Sentiment: Birds, Weeping, Poetics and Song in Kaluli Expression. Philadelphia: University of Pennsylvania Press.

Harnish, David. 2003. Worlds of Wayang Sasak: Music, Performance, and Negotiations of Religion and Modernity. Asian Music 34: 91-120.

Jacoviello, Stefano. 2011. Nusrat Fateh Ali Khan: The strange destiny of a singing mystic. When music travels. Semiotica 183: 319-41. [CrossRef]

Laack, Isabel. 2015. Sound, Music and Religion: A Preliminary Cartography of a Transdisciplinary Research Field. Method and Theory in the Study of Religion 27: 220-46. [CrossRef]

Nijhawan, Michael. 2003. From Divine Bliss to Ardent Passion: Exploring Sikh Religious Aesthetics Through The Dhādī Genre. History of Religions 42: 359-85. [CrossRef]

Qureshi, Regula. 1993. 'Muslim Devotional' Popular Religious Music and Muslim Identity under British, Indian and Pakistani Hegemony. Asian Music 24: 111-21. [CrossRef]

Rasmussen, Anne K. 2005. The Arab Musical Aesthetic in Indonesian Islam. The World of Music 47: 65-89. 